\author{
Review Article \\ www.ijrap.net (ISSN:2229-3566)
}

\title{
CRITICAL APPRAISAL OF ARTAVAVAHA SROTAS AND THEIR MOOLASTHANA WITH CONTEMPORARY MEDICAL SCIENCE: A REVIEW
}

Tina Singhal ${ }^{1 *}$, Ashutosh Kumar Yadav ${ }^{2}$

\author{
${ }^{1}$ Assistant Professor, Department of Rachana Sharir, Government Postgraduate Ayurveda College and Hospital, \\ Varanasi, Uttar Pradesh, India \\ ${ }^{2}$ Associate Professor, Department of Rachana Sharir, Government Postgraduate Ayurveda College and Hospital, \\ Varanasi, Uttar Pradesh, India
}

Received on: 23/02/21 Accepted on: 05/04/21

\begin{abstract}
*Corresponding author
E-mail: drtinasinghal@gmail.com
\end{abstract}

DOI: $10.7897 / 2277-4343.120261$

\begin{abstract}
A female is not only the beautiful but also one of the most important creations of God especially for her ability to reproduce. Ayurveda aims at producing "Supraja" or healthy progeny. In Ayurveda there is a description of Shuddha Shukra (semen) and Shuddha Artava for formation of Garbha (foetus). Artavavaha Srotas (channels of menstrual flow) with its Moolasthana (root) has been mentioned, along with Patho-physiology, clinical conditions and Ayurvedic treatment. Many terms regarding the female reproductive system have been described. After reviewing Artavavaha Srotas, it's very much similar to the female genital system in modern anatomical science. These Srotas (channels) can be interpreted as physio-pathological anatomy i.e., structures of female genital system like uterus, fallopian tube, uterine vessels, ovarian vessels and functionally female hormones both are included in this study.
\end{abstract}

Keywords: Artavavaha Srotas, Artava, Bhag, Artavavaha Dhamani, Uterus.

\section{INTRODUCTION}

In Ayurveda Samhitas, there are so many terms regarding female genital organs like apathyapath, apatyamaarg, kamaatpatra, garbhakosha, garbhakoshth, garbhachhidra, bhag, bhagdwar, bhagnasika, bhagasthi etc. Ayurveda explained a gross picture of different structures or parts of the Artavavaha Srotas (channels of menstrual flow) scattered here and there, similar to the structures of the female reproductive system. Smaratpatra, (also known as Smaramandira, Madanatapatra, Bhagshishnika) is situated in upper portion of the vagina resembling leaf of pippala by Acharya Dalhana, below to this is the orifice for discharge of menstrual blood, similar to the clitoris which is highly stimulated/erectile structure during sexual act. Bhag and Yoni (vagina) are situated very close to each other, but they are not synonyms. There is no description of Bhag under the heading of Yonivyapad diseases, so it seems very much clear that Bhag (vulva) and Yoni are different structures. The term Bhaga in Ayurveda refers to the vaginal introitus of women (hastini) in the books of sexology ${ }^{1}$.

At other place it is said to resemble leaf of pippala. It is of 12 Angular in length, so seems to be the description of circumference of entire vulva instead of introitus of vagina. Vulva is somewhat triangular having its base at mons pubis and apex mid-way between vaginal introitus and anal orifice, with slight convexity of its lateral wall. In Pratyaksha Sharir, according to Gananath Sen, Bhag can be described in 2 ways - Bahirbhag and Antarbhag. Bahirbhag gives the meaning of vulva or external genital organ with seven structures and Antarbhag as yonimarg or vagina ${ }^{2}$. The word Yoni (vagina) in Ayurvedic classics refers to female genitals, uterus and also as individual organs. Its shape resembles the mid part of the conch shell as it is narrow at the introitus and very wide at fornices. It is composed of three Avarta (whorl).
- Prathamavarta comprises vagina and accompanying structures

- Dwitiyavarta comprises cervix and accompanying structures

- Tritiyavarta includes uterus along with its appendages

These three avartas are explained as vagina with its adnexal structures, cervix with adnexa and uterus with adnexa. Dr. Ghanekara interprets these avartas as mucous membranous folds, ridges or rugae like appearance ${ }^{3}$. Other few explanations can also be given for these three avartas as

(A) (i) introitus, (ii) mid vaginal canal and (iii) fornices

(B) (i) thick connective and fibrous layers separating vaginal canal from urinary bladder and urethra anteriorly and rectum and anus posteriorly (ii) muscular layer of vaginal canal and (iii) mucous membrane of vaginal canal.

(C) (i) external genitalia, (ii) vagina and (iii) uterus with adnexa.

(D) (i) submeatal sulcus, (ii) transverse vaginal sulcus (iii) bladder sulcus.

Out of all these four explanations, 'B' or ' $\mathrm{C}$ ' seems to be more analytical because Dalhaņa and Indu have accepted Garbhashaya (uterus) as separate from three Avartas and these Avartas are said to be situated in Garbhamarga (vaginal canal) ${ }^{4}$. Avartas may be interpreted as transverse folds which are present in the vaginal wall of nulliparae allow the vagina to stretch and dilate during coitus and parturition ${ }^{5}$.

Garbhashaya (uterus) is made up of two words Garbha + Ashaya. Garbha (foetus) means foetus and Ashaya means recipient viscous. It means that Garbhashaya is the organ which holds the Garbha for its development. It is situated between Pittashaya and Pakvashaya, (large intestine) near Basti (urinary bladder), between multiple coils of intestine, covered by peritoneum. 
Yoni (vagina) resembles the spirals of the shankha (conch shell) having three spirals; in its third spiral (innermost) lies garbhashaya (seat of the foetus or fundus of the uterus); wise men say that garbhashaya is similar in shape and size to the mouth of Rohit matsya (a kind of fish) ${ }^{6}$.

Women possess one extra eighth Ashaya as Garbhashaya, (uterus) situated in the third Avarta of conch shaped Yoni (vagina). Synonyms of Garbhashaya are Dhara, Garbhashaya, Kukshi, Vipul Srotas etc. Garbhashaya i.e., uterine cavity shapes like a fish namely Rohit. It is triangular, inverted fish shaped with mouth facing downwards and broad tail end upwards. Dalhana says that its mouth is small with a big internal cavity. It resembles the mouth of Rohit fish. Dalhana says that it is hollow inside just like the mouth of a Rohit fish; the Basti (urinary bladder) is behind the Bhaga (vulva) and uterus is above this ${ }^{7}$.

The simile of uterus with mouth of Rohit fish might have been given probably due to two reasons ${ }^{8}$ i.e.

1. Similarity in shape, as both are triangular and hollow inside; the mouth of the fish is flat below and slightly convex above, similarly anterior wall of uterus is slightly flat, while posterior wall is slightly convex.

2. The lips of fish are fleshy and hanging, teeth are not just behind the lips, rather situated slightly behind these giving the appearance of a rounded soft structure, which resembles the cervix of the uterus.

In the context of the situation of uterus the word Pittashaya should not be considered as gallbladder, rather it should be taken as small intestine, the seat of Pittadhara Kala. Pakwashaya refers to the place of almost digested food i.e., large intestine. The uterus is above the sigmoid colon, behind the urinary bladder and multiple coils of the small intestine rest upon the uterus, it is covered with peritoneum and is an intra-abdominal structure, which has been mentioned by Kashyapa and Dalhana. Garbhadharana may be interpreted as uterus containing endometrium i.e., nutritive layer meant for implantation and foetal development.

\section{Artavavaha Srotas}

While considering the concept of Artavavaha Srotas (channel of female reproductive system) it can be understood by its functions, Moolasthana, Viddha Lakshana (retrogression method which means symptoms produced due to injury), or Dushti Lakshana (pathological changes) occurs in Artavavaha Srotas. Acharya Charaka has not mentioned Artavavaha Srotas but Acharya Sushruta has given the detailed description of this Srotas (channel). Artavavaha srotas are two in number, their moola (origin) are garbhashaya and Artavavaha dhamani; injury to these leads to sterility, intolerance of copulation and loss of menstrual flow $^{9}$. As regards the Artavavaha Srotas go in favour of female genital organs in modern science. It is a physio-anatomical structure having Garbhashaya and Artavavahi Dhamani of its Moolasthana.

It is quite related to the female reproductive system of modern science in which the uterus along with the fallopian tube and ovary (structurally) along with ovarian and uterine vessels and hormones (functionally).

Interpretation of Artavavaha Srotas can be done in two waysMacroscopic and microscopic. Macroscopically it is considered as a female reproductive system where menstruation, conception, implantation and foetal development takes place. While microscopically we must go through the physiological aspect of Artavavaha Srotas ${ }^{10}$. When we look upon its physiological aspects, the entire functions in terms of ovulation, menstruation and its hormonal relationship get precipitated by itself. Capillary networks present in the reproductive system also play a significant role in nutrition, development and proper functioning of the whole reproductive system. It clearly indicates that Fertilization, Implantation, nutrition and development of foetus take place in Garbhashaya (uterus) according to Ayurveda texts as well as modern science. Artavavaha Dhamani may be considered as uterine arteries, specially their capillary bed, as these arteries are responsible to carry Artava, two in number, have attachment with uterus and injury to these vessels may result in infertility and amenorrhoea due to absence of proper blood supply to uterus along with endometrium, dyspareunia may also occur due to associated inflammation caused during injury and psychological upset due to amenorrhoea etc. may be interpret ovarian artery as formation of Artava or ovum or ovarian hormone and uterine arteries for excretion of Artava i.e. menstrual blood. In Ayurveda Artava has been mentioned in two ways-one of them is Antah Pushpa and another one is Bahir Pushpa. Both Antah and Bahir Pushpa are interrelated. Bahir Pushpa i.e., Artava Shonita means menstrual blood is an outward manifestation of appropriate work of Antah Pushpa i.e., ovum or Stree Beej (necessary for conception). Here, the present research deal with Artava Shonita i.e., Menstrual Blood. Any injury to the Artavavaha Srotas or its Moolasthana causes symptoms like menstrual disturbances, dyspareunia or even infertility which is also accepted and very well explained by modern science. By all the above arguments concerning Artavavaha Srotas shows reasonable similarities with the female reproductive system.

\section{Moolasthana of Artavavaha Srotas}

Meaning of Moolasthana depend upon the references present in Veda, Purana and Ayurveda Samhitas. In Ayurvedic classics, Moolasthana of any Srotas, means a place from where something originates like Utpatti sthana (origin point of view), a place where something stores i.e., Sangraha sthana (storage) and a place from where some nutrients or Rasa etc. carry as Vahana Sthana (conduction). In females, additional eighth Srotas is explained named as Artavavaha Srotas. Ayurveda mentions that Garbhashaya and Artavavahi Dhamani as a Moolasthana of Artavavaha Srotas. Acharya Ghanekar interpret Artavavaha Srotas as uterus and its arteries i.e., ovarian and uterine arteries ${ }^{11}$. Garbhashaya is mainly responsible for conception, production and expulsion of Artava, from origin point of view. Artavavahi Dhamani can be taken as fallopian tube which conducts Artava (ovum) towards uterus during menstrual phase and Dhamana word refers to contraction, so contraction of fallopian tube conducts the ovum.

Table 1: The terms mentioned in Ayurveda similar to Female Genital System

\begin{tabular}{|c|c|c|}
\hline S. No. & Terms used for Artavavaha Srotas and Stri Prajanan Sansthan & Similar structure In Female genital System \\
\hline 1 & Bhaga & Vulva or introitus \\
\hline 2 & Smaratpatra, kamaatpatra & Clitoris \\
\hline 3 & Yoni & Vagina or Whole Reproductive system \\
\hline 4 & Garbhashaya or Garbhashaya & Uterus \\
\hline 5 & Antarphala & Ovary \\
\hline 6 & Artavavaha dhamani & Fallopian tube or uterine vessels \\
\hline
\end{tabular}


Garbhashaya is a space in which the implantation of fertilized ovum occurs. Yoni resembles "Shankha Nabhi Akriti" and contains three Avarta (circular folds) in its structure. Among these three Avartas, Garbhashaya is situated in Tritiya Avarta of

All the Samhita and scholars of Ayurveda have a unified thought that Artava represents the main and important activities of the females. The commencement of menstrual cycle is an indicative of maturity in females. The organs concerned get well developed and start their functions adequately. Normal menstrual cycle indicates the proper function of the female genital system anatomically as well as physiologically. After deeply reviewing the literature regarding Srotas, it indicates that this is a concept of Physiological Anatomy and Pathological Anatomy. Nowadays researchers are emphasizing on the functional and pathological anatomy rather than theoretical anatomy. Descriptions of Srotas become more appropriate if they are interpreted as functional anatomy and clinical anatomy. The female reproductive system developed by 2 Mullerian ducts embryologically, defines the pair nature of the female genital system. Through Viddha Lakshana of Artavavaha Srotas, we can say that all normal functions are quite possible if the whole system works properly. So Artavavaha Srotas can be interpreted as the whole female reproductive system like uterus, fallopian tube, uterine and ovarian vessels.

\section{DISCUSSION}

When we look at the Female genital system, embryologically this whole system is developed by two Mullerian ducts during the development. This defines the "Copulate" nature of the Artavavaha Srotas as a whole and is perfect even in terms of the analogue of different thoughts from Ayurveda and Modern Anatomical Sciences. There is a sufficient description of the Yoni (vagina) and Garbhashaya (uterus) in the text, which clearly covers the whole genital system of the females. According to Sushruta Samhita there are three "whorls" of the Yoni and these are situated in shape similar to a conch shell and every whorl represents a part of the female genital system. There are so many gynaecological disorders in Ayurvedic texts under the title of Yonivyapad. Here Yoni means the whole female reproductive system i.e., not concerned with vagina only, but also related with uterus, their vessels, hormones etc. The pathology of three clinical entities - infertility, dyspareunia, and amenorrhea described in Artavavaha Srotoviddha Lakshana cannot be limited to a single organ of the female genital system. Finally, Artavavaha Srotas can be understood by the female genital system. No work is complete in terms of studies and research. This research must go on to the next level through clinical studies, functional and pathological anatomy.

\section{CONCLUSION}

So, we can conclude that Artavavaha Srotas in Ayurveda is quite similar to the female reproductive system of modern science. It can be interpreted in two ways - macroscopic and microscopic. Macroscopically it is the female reproductive tract (anatomically) and microscopically it is the capillary network of the reproductive tract (physiologically). Moolasthana means Utpatti Sthana (origin), from where the Artava originates i.e., Garbhashaya (uterus) and Artavavahi Dhamani (fallopian tube or blood vessels
Yoni. In this context Yoni is not only meant for vagina but also for the whole female genital system i.e., from outside to inside, there is Yoni, Garbhashaya mukha and Garbhashaya respectively. (Table 1) and capillaries of uterus). The Concept of female reproductive system is very well explained in Ayurveda in terms of Artavavaha Srotas along with its functional anatomy, clinical conditions and their Ayurvedic treatment in proper manner. The Sushruta as description of Artavavaha Srotas and its Moolasthana clearly indicated that it is closely concerned with the female genital organ.

\section{REFERENCES}

1. Tiwari Premwati, Ayurvediya Prasuti Tantra and Stri roga part, reprint edition Varanasi: Chaukhambha Orientalia; 2009. p. 5.

2. Sen Gananath, Hindi Pratyaksha Sharira, reprint edition Varanasi: Chaukhambha Sanskrit Series Office; 2005. p. 282,284.

3. Ghanekar BG, Sushruta Samhita Sarirsthanam, reprint edition New Delhi: Meharchand Lachhmandas Publications; 2006. p. 175

4. Tiwari Premwati, Ayurvediya Prasuti Tantra and Stri roga part 1, reprint edition Varanasi: Chaukhambha Orientalia; 2009. p. 9-10.

5. Padubidri VG, Daftary SN, Howkins and Bourne Shaw's Textbook of Gynaecology, sixteenth edition New Delhi: Reed Elsevier India Private Limited; 2015. p. 3.

6. Murthy KRS Illustrated Sushruta Samhita, Sharir Sthana, 5:43-44, Reprint edition Varanasi: Chaukhambha Orientalia; 2017. p. 100 .

7. Tiwari Premwati, Ayurvediya Prasuti Tantra and Stri roga part 1, reprint edition Varanasi: Chaukhambha Orientalia; 2009. p. 12.

8. Tiwari Premwati, Ayurvediya Prasuti Tantra and Stri roga part 1, reprint edition Varanasi: Chaukhambha Orientalia; 2009. p. 13.

9. Murthy KRS Illustrated Sushruta Samhita, Sharir Sthana, 9:12, Reprint edition Varanasi: Chaukhambha Orientalia; 2017. p. 151

10. Lahange S M, Bhangare A N. A Critical Review on Artavavaha Srotas as Concept of Female Reproductive System in Ayurveda. Int Gyn \& Women's Health 2018; 1(2): 25-29.

11. Ghanekar BG, Sushruta Samhita Sarirsthanam, reprint edition New Delhi: Meharchand Lachhmandas Publications; 2006. p. 243.

12. Lahange S M, Bhangare A N. A Critical Review on Artavavaha Srotas as Concept of Female Reproductive System in Ayurveda. Int Gyn \& Women's Health 2018; 1(2): 25-29.

\section{Cite this article as:}

Tina Singhal and Ashutosh Kumar Yadav. Critical appraisal of Artavavaha Srotas and their Moolasthana with Contemporary Medical Science: A Review. Int. J. Res. Ayurveda Pharm. 2021;12(2):121-123 http://dx.doi.org/10.7897/2277$\underline{4343.120261}$ 